\title{
Effecting Change through Women's Activism in Liberia
}

\section{Leymah Gbowee}

\begin{abstract}
This article highlights historical issues of injustice and violence against women in conflict-torn societies in West Africa. It provides examples of women's participation in the struggle for freedom and the search for peace and reconciliation, focusing on the role of women in catalysing and supporting the recent peace process in Liberia and Sierra Leone. It is based upon the author's own involvement as a women's activist in Liberia.
\end{abstract}

\section{Envisioning and mobilising for change}

The 'Aba women's riot' in October of 1929, when the women of Aba in Eastern Nigeria demonstrated against high taxes and low prices of Nigerian exports, is one of the most poignant examples of women using their numerical strength, ability to mobilise and their traditional role in African society to advocate for inclusion on an issue that affected their lives (Perham 1937). The legacy and spirit of the Aba women is still alive in West Africa, as women's groups continue to use their numerical strength, sisterhood and shared experiences to effect change.

Change between the mid-1980s to the present has inescapably been plagued by the legacies of civil wars in the region. For 14 years, West Africa, with the Liberian conflict as the igniter, has experienced widespread violence, killings, rape and dehumanisation of people within and across the Mano River Union countries (Liberia, Sierra Leone and Guinee) and Côte d'Ivoire. Women advocating for change in the region have sought to use dialogue to solve ethno-political divisions and end the violence that has affected them personally. In Sierra Leone a 2003 survey showed that over 86 per cent of female abductees and internally displaced persons had been gang raped during the war (GRADOC 2003). Similarly, women in Liberia were also the main targets of rape and other forms of sexual violence. A World Health Organization (WHO) survey carried out in 2005 revealed that 90 per cent of Liberian women had suffered physical and/or sexual violence and that three out of four had been raped. The use of rape as a weapon of war indicated the unique type of battle that women face during wartime; that is, they are the 'violated during the violation, the victims of the victimisation, and the captured of the captors'.

Regrettably, the peace negotiations held to bring an end to these conflicts failed to incorporate the needs and concerns of women. Signed peace agreements also failed to recognise women's roles in and contributions to peacebuilding and postconflict reconstruction. Reacting to their exclusion, West African women have become motivated to employ what is known as the 'women peace activism’ strategy (Ekiyor and Gbowee 2005).

The rationale behind women's peace activism is to promote social justice in West Africa, a region where women remain marginalised and excluded from the major spheres of decision-making. Women's peace activism is not only about advocating for a cessation of physical violence during conflict and wars but also to terminate the physical and structural violence that exists in everyday society. This activism is built on the belief that the systematic engendered forms of violence against women, such as rape, forced prostitution, mutilation, etc. are expressions of a deeper systemic disregard for women characteristic of West African societies in particular but common in most other societies. 


\section{The Women of Liberia Mass Action for Peace Campaign and the Accra Peace Talks 2003}

The international community and the Economic Community of West African States (ECOWAS) pressured the government of Liberia led by Charles Taylor and the belligerent forces Liberians United for Reconciliation and Democracy (LURD) and Movement for Democracy in Liberia (MODEL), to come to the peace table on 4 June 2003, to end the highly destructive civil war that had been raging intermittently for 14 years. The women of Liberia under the banner of the Women in Peacebuilding Network (WIPNET) ${ }^{2}$ had earlier initiated advocacy and non-violent protests to pressure both sides to cease fire unconditionally. Seven women representing various organisations within the network went to Ghana (where the negotiations were being held) to mobilise Liberian refugee women to join the campaign. The women began protesting on the day that the peace talks officially commenced. It was anticipated that the talks would last three weeks, but in reality, they lasted for three months.

Six weeks into the peace talks, the women had tired of the slow progress, the intense shelling and bombing of Monrovia and other regions, and news of approximately 200 deaths per day. Over 200 Liberian women staged a sit-in at the entrance of the conference hall, locking arms to block the exit of delegates and demanding that the leaders of warring factions sign the peace agreement to put an end to the hostility. During the sit-in, the women also demanded that no Liberian delegate would be allowed to leave the conference room for any reason until the agreement was signed. The women said their actions were intended to show to the world that they had finally had enough of the war in Liberia and were taking a stand to safeguard what was left of their society and communities.

The standoff lasted for about two hours, during which the Chief Mediator and other diplomats pleaded with the women to disengage. The women agreed on the condition that the following be observed:

1 That delegates would attend sessions regularly and stop the merrymaking

2 That delegates would refrain from jeering or insulting the women while passing by their protests
3 That the peace agreement would be signed within two weeks or the women would barricade the hall again.

Two weeks later the Comprehensive Peace Agreement (CPA) was signed, marking the end of the Liberian civil war. Many political commentators credited the women's actions as one of the driving forces behind the signing of this agreement. During an interview with the producers of the documentary Pray the Devil Back to Hell, which traced the stories of the women in the peace talks, one of the leaders of the warring factions reported that 'those women were our consciences'.

Liberia had signed many peace agreements during the civil war, but all had collapsed even before implementation had begun. In this context, the women of Liberia were determined to ensure that the CPA signed in August 2003 was implemented to the fullest. However, a major challenge they encountered was simplifying the language of the agreement so that community women could be made readily aware of its contents. In September at the St Teresa's Convent Pastoral Retreat Centre in Monrovia, the Liberian Women's Initiative in partnership with WIPNET organised a two-day consultative meeting. The overall goal was to demystify the CPA and set benchmarks for its implementation. The meeting, which brought together 80 women leaders from across Liberia, aimed to sensitise women to the need for continuous action to ensure the successful implementation of the peace agreement. Community women were equipped to engage the United Nations Missions in Liberia (UNMIL) in line with the CPA timetable when processes were slow in commencing.

Women activists also decided to involve themselves in the Disarmament, Demobilisation and Reintegration (DDR) process. They cooperated with UNMIL to sensitise communities and combatants on the need for them to give up their arms and benefit from skills training programmes. In many communities combatants agreed to give up their arms; some directly to the women, who in turn handed the weapons to the UN; while others were accompanied by women, to be disarmed by the UN.

However, this interaction between the women, the UN and the combatants was not without 
some hitches. For example, during the DDR process, the women of Bong Mines ${ }^{4}$ sent a delegation to Monrovia to enquire from the National Commission for Disarmament, Demobilisation and Reintegration (NCDDR) why the fighters from that area had not been paid for handing over arms in the 'cash for guns' agreement. The delegation, along with the head of WIPNET, ${ }^{5}$ met with the Chairman of the National Transitional Government, Charles Gyude Bryant, and various stakeholders. It became apparent that contrary to what the government was being told by various partners and agencies, payments for combatants were not forthcoming. The delays contributed to riots by combatants in different parts of the city.

The women's intervention not only alerted the government authorities about the flaws of the cash payment system, it also increased awareness of other issues that lacked proper coordination among bilateral partners. For instance, the NCDDR blamed UNMIL for the slow pace of payment, while UNMIL blamed the NCDDR for inefficiency. By the end of the meeting, the women were able to secure firm commitments from the government and bilateral partners to speed up the cash payments to combatants. This is just one of many examples of how community women used advocacy and community awareness to influence key stakeholders (UNMIL, ECOWAS, EU and the Transitional Government) and ensure that the DDR process was successfully carried out.

The Liberia women's actions did not end with the technical 'demilitarising' of society, as they engaged proactively on a number of other issues. Just prior to the commencement of voters' registration in April 2005, women carried out a random survey of women's preparedness to engage in the political process. The majority of the women interviewed said they were unwilling to engage, meaning they were not even willing to participate in the voters' registration process. Their reasoning was that they had not benefited concretely from the governance of Liberia and that the outcome would result in the same 'few persons getting rich at the expense of the masses'. WIPNET shared these findings at a meeting of international bodies involved in election support, and recommended that specific measures should be taken to encourage women to register and vote, so as to avert the disenfranchisement of one of the most important sectors of the population.
Since no action was taken to address these issues a week prior to the end of voter registration in May 2005, the women were invited to a meeting by some of the institutions that they had spoken with earlier. Statistics showed that the number of eligible voters registering was low, due to low voter awareness and apathy among the Liberians, especially women, who for many years had been marginalised in political decisionmaking. To reverse the situation, women from the Christian Women Peace Initiative (CWPI) and the Liberian Muslims for Peace (LIMWOP) under the banner of WIPNET launched a massive voters' registration campaign five days before the end of the registration process.

A total of 200 women formed teams to work in ten different communities, each under a leader responsible for overseeing the groups' activities. Team members had to record the names of individuals they encouraged to register. The entire campaign was single-handedly carried out by women. During the five-day exercise, there was no contact with other organisations that had been accredited by the National Elections Commission (NEG) or funded by the United Nations Development Programme (UNDP) within the ten communities. After five days in ten communities through differently employed strategies, a total of 7,425 individuals were registered to vote.

\section{Effecting change}

The situation of women in West Africa today has not much improved since the time of the Aba women's protests in the colonial era. Despite some important advancements in the public image of women, traditionally (and West African societies are still very traditional) women are still seen largely as second class citizens, who have to advocate for their inclusion in the decision-making processes. Over the last few years, women's roles in peace and security processes, specifically in Liberia and Sierra Leone, has led to important changes in national laws and policies. In Liberia, previously only gang rape was considered an offence by law. In January 2006 a women's advocacy movement led by the Association of Female Lawyers of Liberia (AFELL) helped formulate a new rape bill, which was successfully enacted into law. The new law addresses aspects of rape not provided for in the old law, such as rape with objects, which was common during the conflict. The new law also 
makes rape an 'unbailable' law that is punishable by seven years to life imprisonment.

The 2005 election of Madam Ellen Johnson Sirleaf as Africa's first democratically chosen female president in Liberia is a signal that women's activism has the potential and capacity for changing not just laws and policies but also for deconstructing patriarchal structures that have been used in the past as tools of oppression. However, this raises many questions that have yet to be answered. How do women in West

\section{Notes}

1 Thelma Ekiyor, 1st Annual Women in Peacebuilding Network (WIPNET) Conference 2002.

2 WIPNET is the women's programme developed by Ms Thelma Ekiyor for the West Africa Network for Peacebuilding.

\section{References}

Ekiyor, Thelma and Gbowee, Leymah (2005) 'Women's Peace Activism, the Liberian Women's Experience', in Paul Van Tongeren, Juliette Verhoeven, Malin Brenk and Marte Hellema, People Building Peace II, Boulder, CO and London: Lynne Rienner
Africa ensure that the momentum that has been generated from their activism is passed on from this generation of women to the next? How can the gains be translated into effective advocacy tools for inclusion and empowerment? Scholars, civil society actors, and political figures must provide answers to these questions with not just words, but also with continuous actions that ensure that the status of West African women is elevated so that women are no longer denied their right to political representation.

3 Gini Reticker, Director, Pray the Devil Back to Hell, 2008.

4 Bong Mines is an old mining town in Bong County, central Liberia.

5 Leymah Gbowee coordinated WIPNET Liberia during 2001-5 December 2005.

GRADOC (Gender Research and Documentation Centre of Sierra Leone Survey)(2003) Sierra Leone

Perham, Margery (1937) Native Administration in Nigeria, London: Cass 